\title{
Nutrition, Therapeutics and Environment Impact of Oyster Mushrooms: A Low Cost Proteinaceous Source
}

\author{
Titas Ghosh, Aparajita Sengupta and Arpita Das* \\ Department of Biotechnology, Adamas University, India
}

Submission: January 17, 2019 ; Published: February 07, 2019

*Corresponding author: Arpita Das, Department of Biotechnology, Adamas University, India

\begin{abstract}
Oyster mushrooms have been in our delicacies for hundreds of years, but these mushrooms have lot to offer than to be just taste makers in our dishes. The content of Oyster mushrooms are seen to have therapeutic value alongside of nutritional value. These mushrooms have very high concentration of protein compared to other vegetable sources, also have high concentration of some essential minerals such as vitamins (B,C and D), Selenium, Copper and Potassium. These mushrooms are being used as medicines for over centuries. They have been used as antibacterial, anti-inflammation and antioxidant. Currently they are being tested as potential cancer treatment and anti-tumor. Oyster mushrooms are also used in bioremediation also known as mycoremediation in recent times to remove pollutants from the environment contaminations. This review tries to cover these aspects of the very common Oyster mushrooms.
\end{abstract}

Keywords: Oyster Mushroom; Pleurotus sp; Nutrition; Therapeutics; Mycoremediation

\section{Introduction}

Mushrooms, they fall into the kingdom of Fungi. Fungi are one of the primary decomposers in the ecosystem. They are found throughout the world, living in cryptic manner or sprouting from dead organisms. Fungi are often overlooked as nutritional sources. As many fungi are harmful for consumption, for example, Agaricus xanthodermus, Amanita gemmata, Cudonia circinans, Entoloma sinuatum, Hapalopilus nidulans etc. but a much closer look reveals that they have much more to offer. A lot of mushrooms are actually safe for consuming, like Agaricus bisporus, Lentinula edodes, Cyclocybe aegerita, Pleurotus spp.

Table 1: Systemic position of Pleurotus.

\begin{tabular}{|c|c|}
\hline Systemic Position & \\
\hline Kingdom & Fungi \\
\hline Division & Basidiomycota \\
\hline Class & Agaricomycetes \\
\hline Order & Agaricales \\
\hline Family & Pleurotaceae \\
\hline Genus & Pleurotus \\
\hline
\end{tabular}

Oyster mushrooms (Pleurotusspp) are one of the most common mushrooms in the world which is used as a food source. Originally from Asian origin, but first cultivated in Germany during the first world war as an alternative nutrition source. It is now the third highest in quantity of commercially produced mushroom in the world due to its high nutritional values. It can be cultivated in straw and other media. Systemic classification of Pleurotus sp. is given in Table 1.

The mushrooms are usually seen attached laterally on the surface, and is large enough to be visible by the naked eye [1]. The visible parts are usually the fan shaped or ear shaped cap spanning $5-25 \mathrm{~cm}$ and the stem. They come in variety of colors ranging from white to gray or tan to dark-brown. The margin is rolled inwards towards the stem when it is young and is often lobed or wavy. It has white flesh with variable thickness due to stripe arrangements. The mushroom is seen growing in the forests of temperate and sub-tropical region of the world. They grow on moderate temperature of $20^{\circ} \mathrm{C}$ to $30^{\circ} \mathrm{C}$, with humidity of $55 \%$ to $70 \%$ [2]. Mushrooms can be both beneficial and pathological to plants and animals. Some harmful mushrooms are Malassezia spp. this is a fungus is an opportunistic pathogen, which causes Tinea versicolor in humans. Fungi under the phyla Ascomycota, Zygomycota and Chytridiomycota are known to attack invertebrates [3]. Arthrobotrys oligospora is a pathogen for nematodes [4]. Fungi those who are associated with plants are primarily saprotrophs and decomposers. But mushrooms are not all bad some of them are packed with very high nutritional values they are considered as nature's hidden treasure, as they are 
often time ignored by people. But in the eastern part of the globe people have been using various mushrooms for over thousands of years for traditional medicine for various illnesses. Mushrooms have high concentration of Riboflavin or Vitamin B2, Pantothenic acid or Vitamin B5, and Niacin or Vitamin B3, Selenium, Copper, Potassium, Vitamin D [5,6].

Brown rot fungi and white rot fungi digests or breakdown cellulose and hemicellulose to lignin [3]. Oyster Mushrooms belong in the white rot fungi, are great health supplements. They have low calorie values, and are rich in protein, zinc, chitin, vitamin (B, C and D), essential minerals, trace elements and selenium. Oyster mushrooms have been used as a medicine from ancient times in Asian continental regions. Currently some research work has pointed out that the mushrooms active against hypercholesterolemia conditions, hypertension, diabetes, cancer, infections etc [7] (Figure 1).

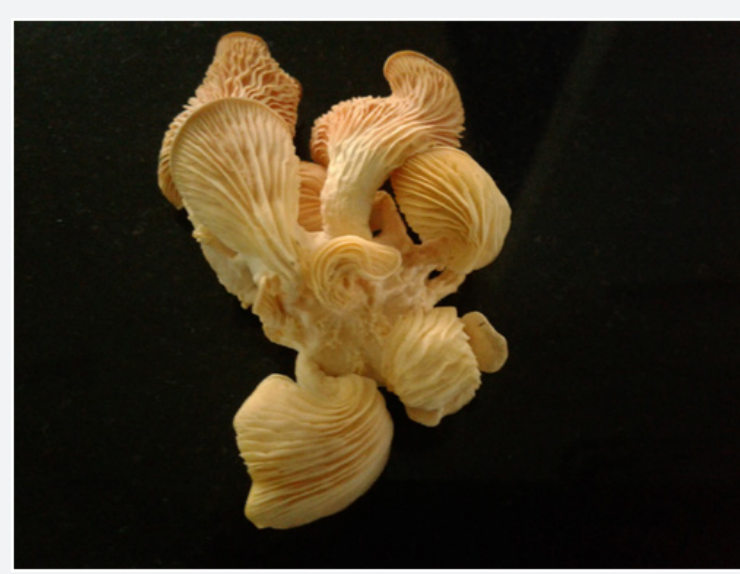

Figure 1: Pleurotus ostreatus grown in laboratory.

\section{Nutritional properties of Oyster Mushrooms}

Oyster mushrooms are rich in nutrition. They contain high amount of protein, with carbohydrate and vitamins. The amount of each varies from species to species. The net content of protein is quite higher in oyster mushrooms, making them a good alternative protein sources for vegetarian and low fat content is promotes it as a very good dietary food.

\section{Carbohydrate}

The main carbohydrate consisting part of the mushroom is the fruiting body. It holds upto $50-60 \%$ of total carbohydrate available [7]. In a study done in 2017 looked into the total carbohydrate contents of three oyster mushrooms Pleurotus florida, Pleurotus eous and Pleurotus sajor-caju. They found that Pleurotus eryngii consists of the most carbohydrate amount, 41g/100g Pleurotus sajor-caju was second containing $38 \mathrm{~g} / 100 \mathrm{~g}$ of carbohydrate [8].

\section{Protein}

Protein is an essential component of mushroom dry weight. In general mushrooms have more protein content than vegetable sources [9]. As an important content of the mushroom dry matter, the content depends upon the composition of the substratum, size of pileus, harvest time, species of mushrooms and flush. As a good source of protein, mushrooms are good alternative for animal meat as they contain some of the essential amino acids which are found in animal protein [7]. It was reported that mushrooms can be an useful dietary supplement for vegetarians. On the dry weight basis, crude protein, the protein content of mushrooms varies between 19/100g and 39/100g [10,11]. Haddad and Hayes [12] reported that protein in A. bisporus mycelium protein content ranges from $32-42 \%$ on dry weight basis. The total nitrogen content of mushroom is from protein amino acids. In which the crude protein value is $79 \%$ compared to $100 \%$ of ideal protein [13].

\section{Fats}

Mushrooms in general have lower fat concentration compared to protein and carbohydrate content. But the fat has more unsaturated fatty acids in it. Even though they have very low amount of fat content, the main fatty acid of oyster mushrooms is linoleic acid. The overall lipid content does vary from species to species; it ranges from 0.2 to $8 \mathrm{~g}$ per $100 \mathrm{~g}$ of dry fruit bodies. In a study by Ram Naraian and Bharti Dixit at Veer Bahadur Singh Purvanchal University studied 3 species of Pleurotus and found that Pleurotus sajor-caju had the most lipid content $(0.61 \mathrm{~g})$ in the fruiting body among the 3 that were tested. Followed by Pleurotus eous (0.53g) and Pleurotus florida (0.46g) [8].

\section{Vitamins}

Mushrooms are well known for their vitamin content as mushrooms are considered one of the best sources of vitamins, for example vitamin B [11,14-17]. Mushrooms are reported to have small amount of vitamin $\mathrm{C}$ and mushrooms in the wild are screened to have a high amount of Vitamin $\mathrm{D}_{2}$ than dark cultivated A. bisporus. [18,19].

\section{Therapeutics of the Oyster Mushrooms}

The term therapeutics refers to the branch of medicine that deals with treatment of disease and how a specific drug effects the body after it is administrated is referred to as the respective drug's therapeutic value. Currently there are foods which are designed to provide dietary supplements that have therapeutic values. these can be whole food such as nuts/seeds, fruits, vegetables, whole grains, broccoli, cabbage, cauliflower, cranberries, fish, flax, garlic, ginseng, oats, red grapes/red wine, soybean, tomato. It is also to be kept in mind that not all mushrooms which are found in the wild are safe to consume, some have compounds which can be fetal if consumed, so only consume mushrooms which are classified as safe to eat.

Oyster mushrooms are considered safe to be consumed and are very easily cultivated. It is full of various kinds of therapeutic effects. 


\section{Antibiotic Effect}

In a research done in 2013 a group of researchers have found that extracts from Oyster mushrooms (Pleurotus eryngii var. eryngii, P. eryngii var. ferulae, $P$. eryngii var. elaeoselini, and $P$. nebrodensis) that had various degrees of antibacterial effect on some reference strains of bacteria (Staphylococcus aureus ATCC25923, S.epidermidis RP62A, Pseudomonas aeruginosa ATCC 15442, and Escherichia coli ATCC10536). Another group of researchers have extracted $P$. florida in four different solvents and it was tested against four bacterial pathogens and one fungal pathogen and found ethanolic extract of mushroom $P$. florida produced minimum inhibitory concentration at $25 \mathrm{mg} /$ $\mathrm{ml}$ against E. coli followed by K. oxytoca $(25 \mathrm{mg} / \mathrm{ml})$, P. murabilis $(75 \mathrm{mg} / \mathrm{ml})$ and Sterptococcus sp. (50mg/ml). Phenolic and tannin constituents of $P$. ostreatus are seen to initiate cell membrane lysis, inhibition of protein synthesis, proteolytic enzymes and microbial adhesions. Petroleum and acetone extract of $P$. ostreatus is seen to be inhibit growth of both gram positive and gram negative bacteria suggesting that $P$. ostreatus has a broad spectrum of antibiotic activity which may come in hand in future due to the fact of the increase of multi drug resistant bacteria $[20,21]$.

\section{Antiviral Effect}

Antiviral chemotherapy aims to discover an antiviral agent that only inhibits viral multiplication leaving the host cells unaffected. Ei Fakharany et al. [22] found that a purified laccase from P. ostreatus mushroom is capable for inhibiting the hepatitis $\mathrm{C}$ virus entry into peripheral blood cells and hepatoma HepG2 cells and its replication.

\section{A Source of Antioxidant}

Antioxidants are substances which help to reduce oxidative stress in the tissue or cell due to reactive oxygen species or ROS. ROS is comprised of super oxides, peroxides and hydroxyl radicals. These usually cause oxidative damage to it. Hence antioxidants are there to react with these ROS and either by destroying them or rendering them ineffective by converting them to some other residue, and prevent any damage to the cell or tissue. Oxidative stress is related to various degenerative diseases such as cancer or hepatotoxicity. Hence the presence of antioxidant in Pleurotus $s p$. can be an effective solution to treat or prevent these conditions. In a study done in 2015 found that antioxidants present in the Pleurotus sp. increased longevity of Mexican fruit flies Anastrepha ludens. The vitamin and selenium content of Pleurotus sp are natural antioxidant in biological systems. Jayakumar et al., found that extract of $P$. ostreatus induced over expression of the catalase gene in aged rats, which prevented oxidative stress on the proteins induced by free radicals, thereby protecting the rats from age related disease [22,23]. Payel Mitra et al. [24] found that free radical scavanging and NOS activation properties of water soluble crude polysaccharide extract of $P$. ostreatus displayed superior antioxidant properties. Consequently P. ostreatus servers as a good source. A acidic polysaccharide was identified from Pleurotus ostreatus has stronge antioxidant effect [24] (Table 2).
Table 2: Antioxidants in various species.

\begin{tabular}{|c|c|c|}
\hline Species & $\begin{array}{c}\text { Antioxidant Com- } \\
\text { pound }\end{array}$ & Reference \\
\hline P. eryngii & Ergothioneine & {$[24]$} \\
\hline P. ostreatus & Ergothioneine & {$[24]$} \\
\hline P. ferulae & $\begin{array}{c}\text { methyl linoleate, } \\
\text { hexadecanoic acid } \\
\text { methyl ester }\end{array}$ & {$[25]$} \\
\hline P. geesteranus & Polysaccharide & {$[26]$} \\
\hline P. citrinopileatus & Ergothioneine & {$[27]$} \\
\hline
\end{tabular}

\section{Effects on Immune System}

A 3-0-methylated heterogalactan has been identified by Pleurotus eryngii has been identified to activate macrophages [24].

\section{Antitumor and Anticancer Activity}

Pleurotus $s p$ has some tumor suppressing properties and this fact has been established for quite a while now. Different types of extract of various Pleurotus $s p$ have proven some anti-cancer activity in cancer cell lines and experimental animal models. But no human clinical trial has been performed properly to relate the results in human model. Hot water extract of Pleurotus $s p$ has been seen to suppress the growth of MCF-7 human breast cancer cells [25]. Farther more P. ostreatus treatment significantly down regulated the expression of biomarkers responsible for colon cancer, like cyclin D1 and Ki-67. This clearly shows that by introducing the P. ostreatus prevented 2-ammino-1-methyle6-phenylimidazo[4,5-b] pyrimidin (PhIP) and dextran sodium sulfate induced mouse colitis-related colonic tumorigenesis without any adverse effect [26]. The first ever report of Pleurotus sp polysaccharide fraction having antitumor potential was published on 1972 by Yoshiyoka et al. Report showed that ethanol isolated and characterized from the P. ostreatus extracts of Pleurotus species had higher antitumor activity towards lung cancer cells $[27,28]$. Hot water and ethanol extracts from fruiting body of oyster mushroom that exerted positive effect on three human solid carcinomas, a lung carcinoma and two cervical carcinomas. Li J et al. [29] reported that Pleurotus ferulae polysaccharides (PFPS) was found to increase the efficiency of therapeutic human papillomavirus dendritic cell-based vaccine [28].

\section{Anti-Inflammatory}

Pleuran isolated from fruiting bodies of Pleurotus $s p$ has anti inflamatory properties. Effect of pleuran (Beta-glucan from Pleurotus ostreatus) on the antioxidant status of the organism and on dimethylhydrazine induced precancerous lesions in rat colon [29]. Various extracts from oyster mushrooms such as P. florida, P. pulmonarius decreased the inflammation in both chronic and acute inflammation condition. Pleurotus citrinopileatus mushroom polysaccharide (PCPS) has been identified to stimulate anti-inflammatory properties during monocyte to macrophage differentiation [31]. 


\section{Mycoremediation}

Mycoremediation is a term used to describe bioremediation done by any fungal species. As a fungus is a point of interest for a long time, eventually they were tested for combatting environmental pollutants. Oyster mushrooms are also found to have some bioremediation capabilities. Da Luz et al. reported to have found Pleurotus ostreatus to degrade Oxo-Biodegradable plastic. Olusola and Anslem in [32] have found Pleurotus pulmonarius to degrade crude oil. Eskander et al. [33] have tested Pleurotus pulmonarius against radioactive cellulose based waste with fruitful results.

One more important part of mycoremediation is the use of SMC or Spent Mushroom Compost. Law et al. [34] reported SMC of Pleurotus pulmonarius was able to reduce around $89 \%$ of Pentachlorophenol (PCP) of $100 \mathrm{mg}$. Another aspect of mycoremediation is bioabsorbtion. Tay et al. [35] has pointed it out that Pleurotus ostreatus is capable of absorbing cadmium from its substrate. Pleurotus sajor-caju was found to absorb zinc. P. florida was seen to absorb cadmium [36]. Pleurotus ostreatus was also seen to absorb Led [34], Copper, Chromium [37].

\section{Conclusion}

Pleurotus spp. has great potential as part of an alternative therapy for the prevention and treatment of oxidative stress, hypertension, and hypercholesterolemia, either directly as food or extracts from fruiting bodies or mycelium. It has now been established that Oyester mushrooms (Pleurotus spp.) are going to be a very important focus in the near future in for nutritional supplement, therapeutic usage and also currently it is being used to clean up the pollution damage that is being caused by humans themselves. Fruiting bodies of oyster mushrooms can be taking regularly as a protein supplement or as an alternative protein supplement in their diet. The low lipid \& high fiber content of the oyster mushroom make it health beneficial food items especially against heart disease and diabetes.

\section{References}

1. Josephine MR (2015) A review on oyster mushroom (Pleurotus spp), International Journal of Current Research 7(1): 11225-11227.

2. Ahmed M, Noorlidah A, Ahmed KU, Borhannuddin BMHM (2013) Yield and nutritional composition of oyster mushroom strains newly introduced in Bangladesh. Pesquisa Agropecuária Brasileira 48(2): 197-202.

3. Carris LM, Little CR, Stiles CM (2012) Introduction to Fungi. The Plant Health Instructor.

4. Barron GL (1977) The Nematode-Destroying Fungi. Canadian Biological Publications, Canada.

5. Bhattacharjya KD, Ratan KP, Nuruddin MM, Kamal UA (2015) Comparative Study on Nutritional Composition of Oyster Mushroom (Pleurotus ostreatus Fr.) Cultivated on Different Sawdust Substrates. Biosensor communication 1(2): 93-98.

6. Salma A (2014) Nutritional and Medicinal Benefts of Mushrooms. Wani Ahmad B, RH Bodha, AH Wani (eds.) Nutritional and medicinal importance of mushrooms. Journal of Medicinal Plants Research 4(24): 2598-2604.
7. Wani Ahmad B, RH Bodha, AH Wani (2010) Nutritional and medicinal importance of mushrooms. Journal of Medicinal Plants Research 4(24): 2598-2604.

8. Naraian R, Bharti D (2017) Nutritional Value of Three Different Oyster Mushrooms Grown on Cattail Weed Substrate. Highten science, India.

9. Bano Z, Rajarathnam S (1988) Pleurotus mushrooms: Part II. Chemical composition, preservation and role an human food. Critical Reviews in Food Science and Nutrition 27(2): 87-158.

10. Weaver KC, Kroger M, Kneeb OLR (1977) Comparative protein studies on nine strains of Agaricus bisporus (Lange) Imbach Mushrooms. J Food Sci 42(2): 364-366.

11. Breene WM (1990) Nutritional and medicinal value of speciality mushrooms. J Food Protect 53: 883-894.

12. Hayes WA, Haddad N (1976) The food value of the cultivated mushrooms and its importance in industry. Mushroom J 40: 104-110.

13. Friedman M (1996) Nutritional value of proteins from different food sources. A review. J Agric Food Chem 44(1): 6-29.

14. Mattila PH, Piironen VI, usir U, Koivistoinen PE (1994) Vitamin D Contents in Edible Mushrooms. J Agr Food Chem 42(11): 2449-2453.

15. Zrodlowski Z (1995) The influence of washing and peeling of mushrooms Agaricus bisporus on the level of heavy metal contaminations. Pol J Food Nutr Sci 4: 23-33.

16. Chang ST, Buswell JA (1996) Mushroom Nutriceuticals. World J Microbiol Biotechnol 12(5): 473-476.

17. Mattila PK, Konko M, Eurola J, Pihlava J, Astola L, et al. (2000) Contents of vitamins, mineral elements and some phenolic compounds in the cultivated mushrooms. J Agric Food Chem 49(5): 2343-2348.

18. Sapers GM, Miller RL, Choi SW, Cooke PH (1999) Structure and composition of mushrooms as affected by hydrogen peroxide wash. J Food Sci 64(5): 889-892.

19. Mattila P, Konko K, Eurola M, Pihlawa JM, Astola J, et al. (2001) Contents of vitamins, mineral elements, and some phenolic compounds in cultivated mushrooms. J Agric Food Chem 49(5): 2343-2348.

20. Ababa Ethiopia (2015) Academia Journal of Microbiology Research 3(1): 014-021.

21. EL-Fakharany EM, Haroun BM, Ng TB, EL-Rashdy MR (2010) Oyster Mushroom Laccase Inhibits Hepatitis C Virus Entry into Peripheral Blood Cells and Hepatoma Cells. Protein Pept Lett 17(8): 1031-1039.

22. Jayakumar T, Thomas PA, Isai M, Geraldine P (2010) An extract of the oyster mushroom, Pleurotus ostreatus, increases catalase gene expression and reduces protein oxidation during aging in rats. Journal of Chinese Integrative Medicine 8(8): 774-780.

23. Payel M, Somanjana K, Krishnendu A (2013) Free Radical Scavenging and NOS Activation Properties of Water Soluble Crude Polysaccharide from Pleurotus ostreatus, Asian Journal of Pharmaceutical and Clinical Research 6(3): 68-70.

24. Yan J, Zhu L, Qu Y, Qu X, Mu M, et al. (2019) Analyses of active antioxidant polysaccharides from four edible mushrooms. Int J Biol Macromol 123: 945-956.

25. Keith RM, Sara KB (2010) Commonly consumed and specialty dietary mushrooms reduce cellular proliferation in MCF-7 human breast cancer cells. Exp Biol Med (Maywood) 235(11): 1306-1314.

26. Andrej J, Shailesh D, Jiahua J, George S, Daniel S, et al. (2010) Pleurotus ostreatus inhibits colitis-related colon carcinogenesis in mice. Int J Mol Med 26(5): 643-650.

27. Yashvant P, Naraian R, Singh VK (2012) Medicinal Properties of Pleurotus Species (Oyster Mushroom): A Review. World Journal of Fungal and Plant Biology 3(1): 2219-4312. 
28. Li J, Aipire A, Zhao H, Yuan P, Li J, et al. (2018) Pleurotus ferulae polysaccharides improve the antitumor efficacy of therapeutic human papillomavirus dendritic cell-based vaccine. Hum Vaccin Immunother 14.

29. Nosál'ová V, Bobek P, Cerná S, Galbavý S, Stvrtina S, et al. (2001) Effects of pleuran (Beta-glucan isolated from Pleurotus ostreatus) on experimenta colitis in rats. Physiol Res 50(6): 575-581.

30. José MRDL, Sirlaine AP, Denise MSB, Marcos RT, Antônio JD, et al (2014) Abiotic and Biotic Degradation of Oxo-Biodegradable Plastic Bags by Pleurotus ostreatus. Plos One 9(11): e107438.

31. Olusola SA, Anslem EE (2010) Bioremediation of a crude oil polluted soil with Pleurotus Pulmonarius and Glomus Mosseae using Amaranthus Hybridus as a test plant. J Bioremed Biodegrad 4: 111.

32. Eskander SB, El-Aziz ASM, El-Sayaad H, Saleh HM (2012) Cementation of bioproducts generated from biodegradation of radioactive cellulosicbased waste simulates by mushroom. ISRN Chemical Engineering, p. 6
33. Law WM, Lau WN, Lo KL, Wai LM, Chiu SW, et al. (2003) Removal of biocide pentachlorophenol in water system by the spent mushroom compost of Pleurotus pulmonarius. Chemosphere 52(9): 1531-1537.

34. Tay CC, Liew HH, Yin CY, Abdul-Talib S, Surif S, et al. (2011) Biosorption of Cadmium ions using Pleurotus ostreatus: Growth kinetics, isotherm study and biosorption mechanism. Korean J Chem Eng 28(3): 825-830.

35. Jibran AK, Milsee MJP (2011) Pleurotus sajor-caju Protein: A potential biosorptive agent. Adv Bio Tech 4: 25-27.

36. Prasad ASA, Varatharaju G, Anushri C, Dhivyasree S (2013) Biosorption of lead by Pleurotus florida and Trichoderma viride. Br Biotechnol J 3(1): 66-78.

37. Javaid A, Bajwa R (2007) Biosorption of Cr (III) ions from tannery wastewater by Pleurotus ostreatus. Mycopathologia 5(2): 71-79.

\section{Your next submission with Juniper Publishers will reach you the below assets}

- Quality Editorial service

- Swift Peer Review

- Reprints availability

- E-prints Service

- Manuscript Podcast for convenient understanding

- Global attainment for your research

- Manuscript accessibility in different formats

( Pdf, E-pub, Full Text, Audio)

- Unceasing customer service

Track the below URL for one-step submission https://juniperpublishers.com/online-submission.php 